DOI: 10.46340/eujem.2021.7.1.14

Lesia Chubuk, PhD in Economics

ORCID ID: https://orcid.org/0000-0003-2217-7117

Taras Shevchenko National University of Kyiv, Ukraine

\title{
DEVELOPMENT OF A REAL PROPERTY MANAGEMENT STRATEGY AIMED AT MAXIMIZING VALUE
}

\author{
Леся Чубук, к. е. н. \\ Київський національний університет імені Тараса Шевченка, Україна

\section{РОЗРОБКА СТРАТЕГІЇ УПРАВЛІННЯ \\ НЕРУХОМИМ МАЙНОМ, СПРЯМОВАНОЇ НА МАКСИМІЗАЦІЮ ВАРТОСТІ}

\begin{abstract}
The methodical bases of using the profitable approach methods of estimation of grain elevator real estate values have substantiated in this article. The features of grain elevator real estate as an object of valuation, which are inseparable from cash flows of real estate and cash flow of existing business, are defined. The fundamental (market) values are estimated by using a discounting method which is based on created model of cash flows from the grain elevator real estate. The author has proposed a method of valuation for management, which is based on the capitalization of the net operating income (NOI) from the main services obtained by grain elevator property (storage, shipment for transport and drying). The method of calculating of adjustment factors for determining net operating income is revealed. The underutilization factor is applied for moving from potential gross income to actual one, and the operating cost ratio allows to obtain net operating income based on actual income. Based on the comparison of the results, obtained by the two methods of income approach, the potential for value growth is revealed and the advantages are argued of using the capitalization of net operating income method for monitoring the value of strategic real estate management. In particular, the significant advantages of the NOI capitalization method are the simplicity of calculations, the convenience of conducting an approximate cost estimate and the ability to diagnose its growth potential. However, there are the disadvantages of the method: loss of accuracy of result estimation, in some cases unrealistic expectations of stable operation of real estate, ignoring atypical and one-time running costs. Using any of these methods of income approach makes possible to identify factors of value growth such as individual factors of income or expenses that form cash flows or net operating income. Thus, the author concludes that the strategy of maximizing of the value of real estate in management is comprehensive, generalizing to strategies aimed on reduce costs and increase revenue.

Key words: strategic real estate management, value, value maximization strategy, real estate valuation, cash flow discounting, capitalization of net operating income, real estate of grain elevator.
\end{abstract}

Постановка проблеми. Важливого практичного значення в сучасних умовах господарювання набуває оцінка вартості об’єктів нерухомості для стратегічного управління. Позиціонування нерухомого об'єкта з часом може змінюватись. Зокрема, у разі тривалого неефективного (збиткового) використання (операційної нерухомості) або тривалої стагнації ринку та зниження капітальної вартості (інвестиційної нерухомості) нерухоме майно може переводитись у другорядний портфель активів, розглядатись як об'єкт, що відчужуватиметься (виставлятиметься на продаж), передаватиметься у оренду тощо.

Виявлення найбільш вдалого моменту для відчуження, передавання часткових прав володіння на нерухоме майно базується на періодичному моніторингу його вартості. 
Ключовими моментами побудови системи моніторингу вартості нерухомості (в процесі розробки стратегії підвищення вартості нерухомого майна) $є$ такі:

- визначення періодичності та причин проведення оцінки (сигналами щодо необхідності проведення оцінки є зниження/підвищення ефективності використання нерухомого майна);

- обрання методологічної бази оцінки вартості (виду вартості, методологічного підходу та методів оцінки, вимог до вихідних даних (показників), способів узагальнення результатів оцінки);

- обмеження щодо використання результатів (сфера винятково внутрішнього чи внутрішнього та зовнішнього управління).

Вибір виду вартості, основних показників та методів оцінки вартості безпосередньо залежить від позиціонування нерухомого майна підприємства за видами (операційна чи інвестиційна нерухомість).

Для оцінки в процесі управління нерухомістю доцільно розраховувати ринкову або внутрішню фундаментальну вартість. Інвестиційна нерухомість під час оцінювання першочергово потребує застосовування методів порівняльного та дохідного підходів. При визначенні ж вартості операційної нерухомості перевага має віддаватись дохідному підходу, представленому методами дисконтування грошових потоків та капіталізації чистого операційного доходу від основних послуг об'єкта нерухомості.

Аналіз останніх досліджень і публікацій. Методологічні засади дохідного підходу, застосовування його методів до оцінки нерухомого майна широко напрацьовані у світовій оціночній практиці. Цим питанням присвячено низку фундаментальних праць таких зарубіжних авторів, як А. Дамодаран ${ }^{1}$,Т. Колер, М. Гоехард і Д. Весселс ${ }^{2}$, Г. Моррі, П. Бенедетто ${ }^{3}$, Е. Шапіро, Д. Маклін, Г. Сам ${ }^{4}, \Gamma$. Тругман ${ }^{5}$, Дж. Хітчер 6 , Дж. Фрідман та Н. Ордуей․ Узагальнені вони і у методологічних положеннях Міжнародних стандартів оцінки щодо активів у вигляді нерухомого майна ${ }^{8}$. Проблеми використання у цілому методів дохідного підходу у вітчизняній практиці вартісної оцінки нерухомого майна відповідно до циклічних змін на ринку комерційної нерухомості досліджувались у публікаціях, зокрема, С. Сівця та І. Левикіної, В. Вороніна, Е. Лянце та М. Мамчин. Проте спеціалізовані питання оцінки вартості для певних цілей діяльності, зокрема, для стратегічного управління нерухомим майном підприємств, практично не висвітлені у вітчизняній науковій літературі. Надзвичайно важливим, на наш погляд, $є$ аспект розробки теоретичних засад та методичного підгрунтя для методів вартісної оцінки, що були б придатними для проведення моніторингу оцінки вартості в процесі стратегічного управління нерухомістю, а також придатними для врахування особливостей власне об'єктів оцінки, як от, наприклад, спеціалізованої елеваторної нерухомості.

Формулювання цілей статті. Мета статті - розкрити методичні та практичні питання оцінки нерухомого майна елеваторів, призначеної для стратегічного управління та максимізації вартості.

Опис основного матеріалу дослідження. Метод дисконтування грошових потоків призначений для застосування до об'єктів, що мають змінні потоки доходів і витрат протягом прогнозного періоду. На противагу цьому, метод прямої капіталізації найбільш доцільний для застосування щодо об'єктів, які мають стабільні, передбачувані суми доходів (на зразок орендної плати за контрактами) та експлуатаційних (операційних) витрат. Тобто, він використовується у випадках, коли: потоки доходів стабільні протягом тривалого періоду часу та становлять значну додатну величину; потоки доходів зростають стійкими помірними темпами. При використані методу дисконтованих грошових потоків основою для розрахунку є дохід від очікуваного використання

\footnotetext{
${ }^{1}$ Damodaran, A. (2012). Investment Valuation: Tools and Techniques for Determining the Value of Any Asset, University Edition. Wiley: John Wiley\&Sons, Inc.,739-763.

${ }^{2}$ Koller, T., Goedhart, M., Wessels, D. and others (2015). Valuation: Measuring and Managing the Value of Companies. Wiley^ John Wiley\&Sons, Inc., 797.

${ }^{3}$ Morri, G., Benedetto, P. (2019). Commercial Property Valuation: Methods and Case Studies. Wiley: John Wiley\&Sons, Inc., 49-51.

${ }^{4}$ Shapiro, E., Mackmin, D., Sam, G. (2012). Modern Methods of Valuation. 11th Edition. Estates Gazette, 135-146, 795-797.

5 Trugman, G. R. (2016). Understanding Business Valuation: A Practical Guide to Valuing Small to Medium Sized Businesses. Wiley, John Wiley\&Sons, Inc., 409-439.

${ }^{6}$ Hitchner, J. R. (2006). Finance Valuation. Applications and Models. John Wiley\&Sons, Inc., 110-142.

${ }^{7}$ Friedman, J. P., Ordway, N. (1981). Income Property Appraisal \& Analysis. Prentice Hall, 124-140, 323-341.

${ }^{8}$ Parker, D. (2016). International Valuation Standards: A Guide to the Valuation of Real Property Assets. Willey-Blackwell, 102-104, 149-151.
} 
нерухомості за ряд прогнозних років (або ретроспективний період), а також виручка від перепродажу об’єкта нерухомості в кінці прогнозного періоду. При використані методу капіталізації доходів у вартість об'єкта оцінки перетворюється дохід за один часовий період (найчастіше, рік).

Чистий операційний дохід (ЧОД) як показник виконує важливу базову функцію - слугує основою для розрахунку вартості та інших показників ефективності використання об'єктів нерухомості. Щодо зв'язку показників ЧОД і грошових потоків від об'єкта, слід зазначити, що за вирахуванням таких витрат як проценти по кредиту та погашення основної суми боргу, платежів учасникам - дивідендів, комісійних брокерам та управляючим нерухомістю, відрахувань до резервних фондів, чистий операційний дохід стає рівним грошовому потоку до оподаткування, а після вирахування податків - грошовому потоку після оподаткування. Специфіка застосування даного показника полягає у тому, що при оцінці вартості об'єктів комерційної нерухомості в рамках дохідного підходу найчастіше капіталізується (метод прямої капіталізації) або дисконтується (метод дисконтування) саме чистий операційних дохід, а не величина грошових потоків. Причина більш широкого використання ЧОД полягає у тому, що при оцінці визначається вартість саме об'єкта нерухомості як такого, а не підприємства (діючого бізнесу), яке ним володіє, а отже до уваги мають братися лише грошові потоки, які генеруються нерухомістю.

Проте у випадку деяких спеціалізованих видів комерційної нерухомості, як, наприклад, елеватори, розділити їх грошові потоки на пов'язані лише з нерухомим майном або лише 3 операційною діяльністю, практично не можливо. 3 позицій характеристики як об'єкта нерухомості елеватор - це будівля для приймання та зберігання масштабних обсягів зерна та приведення його у стан тривалого збереження. Сучасний елеватор складається більшою частиною із механізованих сховищ для зерна, так званих силосів, а також устаткований додатковим елеваторним обладнанням, яке дає змогу сушити, транспортувати та приводити до стану кондиції зерно, що в ньому зберігається.

У вітчизняній господарській практиці елеватори розглядаються як цілісні майнові комплекси (діючий бізнес), що обумовлює, зокрема, необхідність отримання дозволів від Антимонопольного комітету України у випадку взяття їх у оренду. 3 огляду на цю особливість у випадку елеваторів при управлінні нерухомістю доцільно використовувати для оцінки крім класичного методу дисконтування грошових потоків та методів порівняльного продажу, ще й методи оцінки, засновані на капіталізації показника чистого операційного доходу, сформованого по аналогії до об'єктів інвестиційної нерухомості, які здаються в оренду. Методологічні засади та алгоритм оцінки для управління нерухомістю було розглянуто автором у інших власних публікаціях ${ }^{1}$.

Оцінку фундаментальної (ринкової) вартості елеваторної нерухомості підприємства ТОВ «Зернокомплекс «Сиваш» (м. Козятин, Вінницька область) було здійснено за методами дисконтування грошових потоків та капіталізації показника чистого операційного доходу, сформованого за рахунок основних доходів від об'єкта нерухомості (послуг зберігання, сушіння та відвантаження зерна). Підприємство входить до складу об'єднання «Тесла груп», яке станом на 2019 р. налічує 19 елеваторів та відноситься до числа ТОП-10 власників елеваторів за обсягом елеваторних потужностей в Україні.

За даними оперативної звітності про надходження та витрати коштів від усіх видів діяльності за п’ятирічних період (з 2015-2016 маркетингового року по 2019-2020 рік) та прогнозу на 20202021 рік підприємства було побудовано модель грошового потоку (за схемою на власний капітал) та на їі основі реалізовано окремі прикладні методики дослідження ризиків і оптимізації витрат. Зроблено припущення про початок постпрогнозного періоду та стабілізацію приросту грошових потоків у моделі починаючи з 2022 р. Основні характеристики об'єкта елеваторної нерухомості: справедлива вартість (придбана у 2010 р.) - 3,2 млн дол. (25,92 млн грн), ємність - 53 тис. тонн, річний оборот за 2015-2016 р. - 60 тис. т. (1,13 разів на рік). Значні витрати на обладнання та ремонт протягом 2015-2018 років були пов'язані із будівництвом складу ємністю 8 тис. тонн зерна.

При проведенні розрахунків за методом дисконтування грошових потоків використовувався модуль «Оцінка бізнесу» програми Project Expert і модель грошових потоків від власного капіталу. У процесі оцінки вартості залучались дані про актуальні значення ставок податків (податку на прибуток, ПДВ, ССВ). Ставка дисконту була обрана у розмірі 16\%, що відповідає рівню середньої

\footnotetext{
${ }^{1}$ Chubuk, L. (2014). Methods of aggregate valuation of the warehouse real estate by income approach. Economics and management: problems of science and practice. Collection of scientific articles. Nuremberg: Germany Publisher SWG imex GmbH, 1, 316-320.
} 
ринкової депозитної ставки по довгострокових депозитах для суб'єктів господарювання для року початку дослідження (2015 р.) за даними Національного банку України.

Підсумкова формула обчислення вартості за методом дисконтування грошових потоків має вигляд:

$$
V=P V_{\text {прогн. }}+P V_{\text {постпрогн. }}
$$

де:

$P V_{\text {прогн. }}$ - вартість нерухомості (підприємства), визначена за методом дисконтування грошових потоків (на початок прогнозного періоду);

$P V_{\text {постпрогн. }}$ - вартість нерухомості (підприємства), визначена за моделлю Гордона (на початок прогнозного періоду).

Вартість нерухомості (підприємства), визначена за методом дисконтування грошових потоків:

$$
P V_{\text {прогн. }}=\sum_{t=1}^{n} \frac{C F_{t}}{(1+i)^{t}}+\frac{V_{r}}{(1+i)^{N}},
$$

де:

$C F_{t}$ - грошовий потік доходів, що надходить у $\mathrm{t}$ період;

$i$ - ставка дисконту (очікувана норма дохідності на вкладений капітал);

$V_{r}$ - реверсія (вартість нерухомого майна або вартість перепродажу бізнесу (підприємства) на кінець періоду прогнозування;

$t_{-}$порядковий номер періоду (року), $t=\overline{1 \ldots N}$;

$N$ - порядковий номер останнього року прогнозного періоду.

Постпрогнозна (термінальна) вартість нерухомості (підприємства) за моделлю Гордона на кінець прогнозного періоду:

$$
F V_{\text {пост.прогн. }}=\frac{C F_{N+1}}{R-g}=\frac{C F_{N} \cdot(1+g)}{(R-g)},
$$

де: капітал);

$C F_{N+1}$ - грошовий потік доходів за перший рік постпрогнозного (залишкового) періоду;

$R$ - ставка капіталізації (дорівнює ставці дисконту, очікуваній нормі дохідності на вкладений

$g$ - довгостроковий темп зростання грошового потоку;

$N$ - порядковий номер останнього року прогнозного періоду.

Постпрогнозна вартість нерухомості (підприємства), яка визначена на кінець прогнозного періоду, еквівалентна до вартості реверсії, що може бути виручена від перепродажу нерухомого майна (підприємства) на кінець прогнозного періоду перед початком постпрогнозного.

Постпрогнозна (термінальна) вартість нерухомості (підприємства) за моделлю Гордона на початок прогнозного періоду:

$$
F V_{\text {пост.прогн. }}=\frac{C F_{n+1}}{(R-g) \cdot(1+R)^{N}}=\frac{C F_{n} \cdot(1+g)}{(R-g) \cdot(1+R)^{N}} .
$$

Таким чином, вартість нерухомого об'єкта у прогнозному періоді визначалась шляхом дисконтування (формула 2), а у постпрогнозному (термінальна вартість) - шляхом капіталізації за моделлю Гордона 3 наступним дисконтуванням станом на останній рік прогнозного періоду (формули $3-4)$, а загальна фундаментальна вартість нерухомості - як сума теперішніх вартостей у прогнозному та постпрогнозному періодах (формула 1). Ставки дисконту та капіталізації формувались відповідно: ставка дисконту - як очікувана норма дохідності на інвестиції, ставка капіталізації - обиралась на рівні ставки дисконту за припущення про невизначено тривалий період дохідного використання нерухомості з вирахуванням стабілізованих помірних темпів зростання грошових потоків.

Окремі вихідні дані (ставку дисконту) та одержані результати представлено у табл. 1. При оцінці за моделлю Гордона було зроблено припущення про помірний довгостроковий темп зростання грошового потоку у постпрогнозному періоді на рівні $3 \%$ річних. 
Результати оцінки вартості об'єкта елеваторної нерухомості методом дисконтування грошових потоків

\begin{tabular}{|c|l|c|}
\hline №п/п & \multicolumn{1}{|c|}{ Показник } & \multicolumn{1}{|c|}{ Значення } \\
\hline 1 & Ставка дисконту, \% & 16811541 \\
\hline 2 & $\begin{array}{l}\text { Теперішня вартість грошових потоків протягом ретроспективного } \\
\text { та прогнозного періоду (на дату оцінки), грн }\end{array}$ & 96754595 \\
\hline 3 & $\begin{array}{l}\text { Вартість в постпрогнозному періоді (за моделлю Гордона) } \\
\text { (на кінець прогнозного періоду), грн }\end{array}$ & 32739937 \\
\hline 4 & Теперішня вартість у постпрогнозному періоді (на дату оцінки), грн & 49551478 \\
\hline 5 & Загальна вартість, грн & 14,8 \\
\hline 6 & $\begin{array}{l}\text { Співвідношення вартостей у прогнозному та післяпрогнозному } \\
\text { періодах, \%: }\end{array}$ \\
\hline & - прогнозний період & 85,2 \\
\hline
\end{tabular}

Джерело: розраховано за даними підприємства ТОВ «Зернокомплекс «Сиваш» (об'єднання «Тесла груп»).

Показовим $є$ співвідношення вартостей прогнозного та постпрогнозного (термінального) періодів. Оскільки на кінець прогнозного періоду було досягнуто позитивного значення чистої приведеної вартості грошових потоків, то потенціал зростання вартості у постпрогнозному періоді за умов досягнення помірних позитивних темпів зростання грошових потоків $\epsilon$ досить значним.

Оцінка вартості за методом капіталізації чистого операційного доходу здійснювалась y MS Excel. Розрахунок показника ЧОД (середнє значення за період 2016 - 2021 рр.) було здійснено на основі даних про доходи від послуг зберігання, відвантаження на транспорт та сушіння зерна. Деякі вихідні дані та результати оцінки вартості нерухомості представлено у табл. 2.

Таблиця 2

Вихідні данні та результати оцінки вартості об'єкта елеваторної нерухомості методом капіталізації чистого операційного доходу від основних послуг за 2016 - 2021 маркетинговий роки

\begin{tabular}{|c|l|c|c|c|c|c|}
\hline $\begin{array}{c}\text { № } \\
\text { п/п }\end{array}$ & \multicolumn{1}{|c|}{ Показник } & $2016 / 2017$ & $2017 / 2018$ & $2018 / 2019$ & $2019 / 2020$ & $2020 / 2021$ \\
\hline 1 & $\begin{array}{l}\text { Потенційний валовий дохід } \\
\text { від основних послуг (ПВД), } \\
\text { грн }\end{array}$ & 14038106 & 15987253 & 18113534 & 20434723 & 23321440 \\
\hline 2 & $\begin{array}{l}\text { Коефіціснт } \\
\text { недозавантаження }\end{array}$ & 0,1554 & 0,1554 & 0,1554 & 0,1554 & 0,1554 \\
\hline 3 & $\begin{array}{l}\text { Дійсний валовий дохід } \\
\text { (ДВД), грн }\end{array}$ & 11857114 & 13503437 & 15299374 & 17259938 & 19698168 \\
\hline 4 & $\begin{array}{l}\text { Коефіціснт операційних } \\
\text { витрат }\end{array}$ & 0,5894 & 0,5894 & 0,5894 & 0,5894 & 0,5894 \\
\hline 5 & $\begin{array}{l}\text { Чистий операційний дохід } \\
\text { (ЧОД), грн }\end{array}$ & 4868064 & 5543980 & 6281321 & 7086251 & 8087292 \\
\hline 6 & Коефіціснт капіталізації & 0,1687 & 0,1687 & 0,1687 & 0,1687 & 0,1687 \\
\hline 7 & Вартість, грн & 28861978 & 32869374 & 37240952 & 42013255 & 47948270 \\
\hline 8 & Середнс значення ЧОД, грн & 6802281 & - & - & - & - \\
\hline 9 & $\begin{array}{l}\text { Вартість на основі } \\
\text { середнього ЧОД, грн }\end{array}$ & 40329642 & - & - & - & - \\
\hline
\end{tabular}

Джерело: розраховано за даними підприємства ТОВ «Зернокомплекс «Сиваш» (об'єднання «Тесла груп»). 
Аналіз результатів оцінки вартості за даними табл. 1 та 2 показує, що загальна вартість нерухомості станом на дату оцінки, що відповідає початку періоду, в обох випадках $є$ вищою від ціни придбання, оскільки враховує потенціал зростання чистого операційного доходу та грошових потоків за майбутній період. Оцінка вартості за методом капіталізації середнього чистого операційного доходу очікувано дає більш консервативний результат, ніж оцінка за методом дисконтування грошових потоків (40,329 тис. грн проти 49,551 тис. грн). Це пояснюється включенням до складу чистого операційного доходу лише основних послуг, а також врахуванням темпу зростання доходів за невизначено тривалий постпрогнозний період при оцінці методом дисконтування. Вартість, яка визначена для кожного окремого року періоду за методом капіталізації ЧОД, має тенденцію до зростання, відображаючи таким чином, підвищення ефективності використання елеваторної нерухомості. Розмір чистого операційного доходу, а отже, вартість нерухомості зростає зі збільшенням обороту зберігання зерна та зростанням цін на послуги (обсягів виручки від реалізації основних послуг), а також зі зменшенням частки операційних витрат у дійсному валовому доході. У випадку перевищення операційними витратами дійсного валового доходу вартість не визначалась (2015 - 2016 маркетинговий рік), оскільки ії значення було б від'ємним, що суперечить вихідним припущенням щодо застосування методу капіталізації.

Послідовність та формули для розрахунку ЧОД.

Розрахунок вартості об’єкта нерухомості здійснювався за формулою капіталізації ЧОД:

$$
V=\frac{\text { ЧОД }}{R}
$$

де: $\mathrm{R}$ - ставка (коефіцієнт) капіталізації.

Потенційний валовий дохід від основних послуг об'єкта нерухомості:

$$
\text { ПВД }=Q \cdot P \text {, }
$$

де: $\mathrm{Q}$ - кількість (обсяг) основного виду послуги, що надається нерухомістю;

$\mathrm{P}$ - ціна (тариф) за одиницю послуги.

Дійсний (ефективний) валовий дохід:

$$
\text { ДВД }=\text { ПВД }- \text { В + ІД, }
$$

або

$$
\text { ДВД }=\text { ПВД } \cdot(1-K)+\text { ІД, }
$$

де: $\quad$ В - втрати від неповного завантаження потужностей об’єкта (зменшення оборотності);

ІД - інші доходи (від інших видів послуг).

За аналогією до показника ЧОД для комерційної нерухомості, який враховує типовий відсоток втрат від недоздавання площ об'єкта у оренду та втрат від недозбору орендних платежів, при побудові ЧОД для операційної нерухомості запропоновано використовувати коригувальний коефіцієнт, що відображає відхилення обороту елеваторної нерухомості у напрямку зниження від середньої (типової) кількості оборотів / (типового) рівня завантаження. Призначення коефіцієнта - відобразити вплив зміни доходів від інших послуг, крім зберігання та сушіння, на величину ПВД, а надалі - ЧОД.

$$
K=1-\left[\frac{X_{1}}{X_{0}}\right]^{m},
$$

де:

$K-$ коефіцієнт втрат від зменшення завантаження потужностей зберігання (коефіцієнт недозавантаження);

$X_{1}$ - обсяги завантаження потужностей зберігання у поточному періоді;

$X_{0}$ - оптимальні обсяги завантаження потужностей зберігання відповідно до очікуваного коефіцієнта оборотності;

$m$ - коефіцієнт гальмування ціни $(0<m \leq 0,6 \ldots 0,7)$. 


$$
\text { ЧОД = ДВД - ОВ, }
$$

або

$$
\text { чОД }=\text { ДВД } \cdot\left(1-\kappa_{0 в}\right),
$$

де:

ДВД - дійсний валовий дохід;

$\mathrm{OB}$ - операційні витрати (за винятком заборгованості по кредитах, податках та амортизаційних відрахувань, включаючи резерв на заміщення); доходу.

Ков - коефіцієнт операційних витрат, відношення операційних витрат до дійсного валового

Частка операційних витрат у дійсному валовому доході для розрахунку ЧОД була визначена як середнє значення такої частки по роках за аналізований період (середня геометрична), за виключенням років із нетипово високим рівнем витрат на будівництво та придбання обладнання.

Коефіцієнт капіталізації розраховано, базуючись на ануїтетному методі рекапіталізації (модель Інвуда), за формулою:

$$
R=i+\frac{i}{(1+i)^{n}-1}
$$

де: $\quad i$ - очікувана норма дохідності на вкладений капітал;

$n$ - термін використання об’єкта оцінки (термін економічного життя).

Термін економічного життя прирівняний до мінімального терміну корисного використання об’єкта (20 років), а очікувану норму дохідності обрано на тому ж рівні, що й ставку дисконту для розрахунку NPV у попередньому випадку (16\%).

Таким чином, за моделлю Інвуда (ануїтетною рекапіталізацією) ставку капіталізації для першого періоду розрахунку (2015 - 2016 маркетингового року) розраховано у розмірі:

$$
R=0,16+\frac{0,16}{(1+0,16)^{20}-1}=0,1687 .
$$

Щодо інших видів нерухомого майна (з доступною та достовірною інформацією про об'єкти аналоги і вартість їх продажу) при визначенні ставки можливим є також використання ринкової екстракції для однорідних та різнорідних об’єктів.

Для однорідних об'єктів:

$$
R=\frac{1}{n} \sum_{i=1}^{n} R_{i}
$$

де: $\quad R$ - ставка капіталізації об'єкта оцінки;

$R_{i}$ - ставка капіталізації і-го аналога об'єкта оцінки, $i=\overline{1 \ldots n}$;

$$
R_{i}=\frac{I_{i}}{V_{i}}
$$

де: $\quad I_{i}-$ періодичний дохід від і-го аналога об'єкта оцінки;

$V_{i}$ - вартість і-го аналога об'єкта оцінки.

Для різнорідних об'єктів:

$$
R=\sum_{i=1}^{n} R_{i} \cdot W_{i}^{2}
$$

де:

$W_{i}^{2}$ - ваговий коефіцієнт і-го аналога об'єкта оцінки, отриманий на основі вирішення матриці порівняння характеристик об'єктів. 
Порівняння результатів оцінки вартості за двома застосованими методами показує, що класичний метод дисконтування грошових потоків має такі переваги:

- можливість технічного спрощення розрахунків за допомогою програмних засобів;

- виявлення потенціалу зростання вартості у постпрогнозному періоді за умов дохідного функціонування невизначено тривало.

Недоліки методу дисконтування грошових потоків:

- необхідність значного масиву даних для розрахунку теперішньої (приведеної) вартості у прогнозному (або ретроспективному) періоді;

- складність прогнозування номінальних грошових потоків та врахування чинників інфляції;

- неможливість проведення “точкової” оцінки (базуючись на даних про грошові потоки кожного окремого періоду (року)).

Переваги методу капіталізації чистого операційного доходу, у свою чергу, такі:

- простота розрахунків;

- зручність проведення приблизної оцінки вартості за даними одного періоду (року, останніх 12 місяців) та організації відслідковування динаміки вартості на регулярній основі.

Недоліки методу капіталізації:

- втрата точності оцінки;

- очікування стабільного функціонування об’єкта нерухомого майна (що не завжди є реалістичними);

- відсутність врахування нетипових, одноразових операційних витрат.

Разом з тим, у випадку використання будь-якого із вказаних методів дохідного підходу для моніторингу вартості створюється можливість виявлення чинників ії зростання, а саме окремих статей доходів або витрат, які формують грошові потоки і чистий операційних дохід.

Розробка стратегії управління вартістю, крім оцінки її розміру передбачає також розробку заходів впливу на підвищення вартості, визначення відповідності розміру вартості цілям власника та механізми прийняття рішень щодо розпорядження нерухомим майном на підставі ідентифікації вартості, зокрема, утримання (збереження), відчуження (звільнення), розвиток (трансформація, зміна цільового призначення, способів використання).

Отже, стратегія підвищення вартості може розглядатись як комплексна, узагальнююча відносно інших двох основних стратегій, а саме зменшення витрат та підвищення доходів, адже $є$ їх результуючим наслідком. Найбільш принциповими аспектами розробки такої стратегії $\epsilon$ обрання методики оцінки вартості для управління нерухомістю та чіткого механізму прийняття рішень щодо реалізації права власності на нерухоме майно відповідно до цілей власника.

\section{References:}

1. Damodaran, A. (2012). Investment Valuation: Tools and Techniques for Determining the Value of Any Asset, University Edition. Wiley: John Wiley\&Sons, Inc.[in English].

2. Koller, T.,Goedhart, M., Wessels, D. and others (2015). Valuation: Measuring and Managing the Value of Companies. Wiley^ John Wiley\&Sons, Inc.[in English].

3. Morri, G., Benedetto, P. (2019). Commercial Property Valuation: Methods and Case Studies. Wiley: John Wiley\&Sons, Inc. [in English].

4. Shapiro, E., Mackmin, D., Sam, G. (2012). Modern Methods of Valuation. Estates Gazette.[in English].

5. Trugman, G. R. (2016). Understanding Business Valuation: A Practical Guide to Valuing Small to Medium Sized Businesses. Wiley: John Wiley\&Sons, Inc. [in English].

6. Hitchner, J. R. (2006). Finance Valuation. Applications and Models. Wiley: John Wiley\&Sons, Inc. [in English].

7. Friedman, J. P., Ordway, N. (1981). Income Property Appraisal \& Analysis. Prentice Hall. [in English].

8. Parker, D. (2016). International Valuation Standards: A Guide to the Valuation of Real Property Assets. WilleyBlackwell.[in English].

9. Chubuk, L. (2014). Methods of aggregate valuation of the warehouse real estate by income approach. Economics and management: problems of science and practice. Collection of scientific articles. Nuremberg: Germany Publisher SWG imex GmbH, 1. [in English]. 